\title{
The influence of transformational policies on the operational competitiveness of South African businesses
}

\author{
L.P. Krüger \\ Operations, Quality and Project Management, University of South Africa, \\ PO Box 392, Unisa 0003, Republic of South Africa \\ krugelp@unisa.ac.za
}

\begin{abstract}
Since the dawn of democracy in South Africa in 1994, transformational policies such as black economic empowerment (BEE) and affirmative action (AA) have increasingly and inextricably become part of the everyday political, economic and social life of its populace. As a result, South African businesses are subject to a whole array of mandatory regulations which ostensibly influence their operational capabilities to effectively and efficiently compete in national and global markets. In a survey of the largest 500 (including the top 100 JSE listed) companies in South Africa, it appears that transformational policies are positively supported and endorsed, although their impact on the operational competitiveness of these companies is largely unclear and unknown. A number of warning signs, however, are now being detected from reports in the popular media and in the academic literature about the possible negative consequences of such policies. BEE malpractices, which basically result in the continuation of past injustices against the majority of poor and unskilled people of the country, are becoming increasingly evident. Even more alarming is the fact that the corruption, nepotism and self-enrichment that accompany most BEE transactions are attributed to the ruling ANC political elite.
\end{abstract}

*To whom all correspondence should be addressed.

\section{Introduction}

The current South African government, formed by the African National Congress (ANC) following the first, allparty democratic elections in April 1994 (which the ANC won with a more than two-thirds majority), has done away with or altered previous legislation and enacted many new pieces of legislation - laws that impact on the daily political, economic and social lives of the country's populace. Accompanying these changes is a full array of policies, procedures and legal requirements that have been introduced over the last 15 years, leading to widespread sweeping changes designed to transform South Africa into a nonracist, non-sexist, peaceful and prosperous society. In the business world, these transformational policies, which include black economic empowerment (BEE) and affirmative action (AA), have also directly impacted on the way businesses are managed, including their operations management. From an operations management perspective, Slack, Chambers and Johnston (2010) note that a business designs, plans and controls its operational processes in order to achieve certain performance objectives that its customers or clients regard as important. The performance objectives usually a combination of improved quality, lower costs, high speed, greater dependability and/or more flexibility represent the competitive operations priorities (COPs) that management will attempt to pursue. In this context (i.e. transformational policies and business) it is therefore necessary to consider the potential influence of BEE and AA on the operational capabilities and hence the competitiveness of South African businesses.

\section{Background: The 2009 empirical study - competitive operations priorities}

In 2009 a study was commissioned ${ }^{1}$ using a sample of the largest 500 (including the top 100 Johannesburg Securities Exchange [JSE] listed) companies in South Africa. This study focused on determining which of the specified COPs, such as low cost, high quality, speed, dependability and flexibility, were deemed to be the most important for competing in national (local) and/or international markets in the immediate and medium-term future. The primary purpose of this study was to compare the 2009 results with those of a previous study completed by Krüger (1997) in order to determine whether any shifts in priority and/or relative strengths had occurred over the past 13 years. The 2009 study was also broader its focus and included service providers (rather than only traditional manufacturers). The 2009 study had a further, explicit secondary objective, namely to investigate the influence of so-called "transformational policies" such as BEE and AA on the competitiveness of South African businesses. While the results for the main part of the 2009 study (i.e. the current and future importance of COPs in competing better - both nationally and internationally) were reported in an earlier article by Krüger (2010), this article focuses on the results of part $\mathrm{D}$ of the survey questionnaire, namely the influence of transformational policies on the COPs and general competitiveness of South African businesses. It should be recognised from the outset that this particular topic is

\footnotetext{
${ }^{1}$ Ms Ilja de Boer was appointed as the research consultant to assist with the design and development of the electronic questionnaire, the administration of the survey, data capturing and subsequent statistical analysis.
} 
generally perceived as a sensitive issue in the context of South Africa's new democracy, given its past history of political, economic and social injustices based on purely racial divisions.

\section{Literature review}

\section{Introduction}

The theoretical foundation that provided the platform for the initial 1996 and the subsequent 2009 research projects is well documented in a comprehensive research report, and summarised in (Krüger, 1997:138-140). The following three main points of focus in the literature review were covered in that article: (1) the evolution of manufacturing-based strategies and their potential to improve business's competitive capabilities (Hayes \& Wheelwright, 1984; (2) the use of various aggregated terms such as strategic manufacturing priorities (SMPs) and performance objectives (POs) to indicate a collective of required operations capabilities (i.e. high quality, low cost, high speed, greater dependability and more flexibility) (Slack et al., 2010); and (3) accepting the need to make trade-offs between the different SMPs owing to differences in customer requirements, competitor actions and the specific stage of the product or service in its life cycle (Hill, 1985).

In an update of the literature from 1996 to 2009, Krüger (2010) noted a number of important developments in the context of operations strategies. These were as follow:

(1) the continued interest in the research topic (operations strategy)

(2) the improved sophistication of the research conducted in the field and the significant increase in empirical testing of various theoretical models of operations strategy for casual interrelationships

(3) the enlarged scope of the research topic through a number of new linkages reported with other theoretical constructs, not only in the operations domain, but also in the context of financial, marketing and supply chain management

(4) the reaffirmation of the main theoretical focus points (see previous section), from which the conceptual framework for the initial research was developed, which improves the support for the framework

(5) the possible link of the specific research focus to some broader or more general concepts (including competiveness and sustainability), which indicate that certain niche competences and expertise can be developed by companies in specific industry clusters

(6) the continued apparent lack of universal consensus on the use of terminology, specific performance factors or objectives, methods of measurement, levels of acceptable to superior performance and models of operations strategy - note that the term, "COPs", which was used in the 2009 survey, was derived from the concept of competitive priorities (Evans \& Collier,
2007:122) and was adapted to reflect an operations management focus

(7) the prevalence of similar studies being conducted in other areas of specialisation and certain new ideas directed to advancing research in operations strategy

As indicated earlier, one of the new focus points (and also an explicit secondary objective of the 2009 research study) was to investigate the influence of so-called "transformational policies" such as BEE and AA on the operational competitiveness of South African businesses. The academic literature on the topic of transformation in South Africa is still relatively limited in depth, and includes many gaps (including BEE dealings, the challenges and the factors necessary for success) (Fauconnier \& Mathur-Helm, 2008), but does not lack the intense and vibrant debate that is characteristic of the general media (Ponte, Roberts \& Van Sittert, 2007). The accredited articles that have been published, however, do cover a wide array of topics in the transformation agenda. These topics range from specific industry experiences in implementation (e.g. the mining, agriculture and banking sectors) (Booysen, 2007) to much higher levels of academic endeavour (Vermeulen \& Coetzee, 2006) and intellectual discourse (Du Toit, Kruger $\&$ Ponte, 2008). Another apt example of such a higher level of discourse may be found in a critique by Kruger (2010:76) of a South African television drama script that focuses on the impact of transformation in post-1994 society in which the "... visual elements highlight the glamour of conspicuous consumption by the BEE elite and those who emulate them ...”.

Clearly, South Africa in this context of transformation and the application of BEE and AA may be considered somewhat unique in comparison with other countries. Hipkin (2004:722) highlights two specific aspects of this uniqueness. Firstly, South Africa is classified as a developing country in terms of its economic position and competiveness in world markets; it finds itself in a "dual world situation", because it "exhibits some favourable attributes of a developed economy as well as the negative characteristics of the poorest countries, and lags behind many of its competitors ...". Secondly, South Africa has undergone major political changes since 1994 and must accommodate "... factors peculiar ..." to the country and "issues in the broader context such as affirmative action, employment equity, employee empowerment ..." which “... have introduced additional dimensions to the management of South African firms".

\section{South Africa's competitive position in terms of the Institute for Management Development's (IMD's) world rankings}

Probably the best-known and frequently cited authoritative source of world competitiveness rankings is the IMD World Competitiveness Yearbook (WCY), which has been published by the IMD Competitiveness Centre annually since 1989 (IMD, 2010a). More than 50 countries are ranked on their overall competitiveness and on the following four leading indicators: economic performance, government efficiency, business efficiency and infrastructure. The 
IMD's (2009) definition of competitiveness is as follows: "How nations and businesses are managing the totality of their competitiveness to achieve greater prosperity". South Africa's overall position in 2009 (when the empirical part of this research was conducted) was $48^{\text {th }}$ out of the 57 nations ranked. This overall position improved to $44^{\text {th }}$ out of 58 in 2010, mainly owing to the improvement in government efficiency and infrastructure - there was a slight decline in business efficiency and the country's economic performance remained unchanged. South Africa's overall competitiveness performance, according to the IMD ranking, including its performance in the four main indicators for the period 2006 to 2010, is illustrated in Figure 1. Most of the competing nations in the first five positions above and below South Africa's overall competitiveness ranking are also classified as developing countries (e.g. the Philippines, Peru, Hungary, Colombia and Mexico - see Table 1). South Africa's relative competitive performance in 2010 in terms of the 20 individual competitive areas is illustrated in Figure 2 and needs to be understood against the so-called "competitive landscape" on a scale of 1 to 5 , where $5=$ very good, $4=$ good, $3=$ average, $2=$ poor and $1=$ very poor.

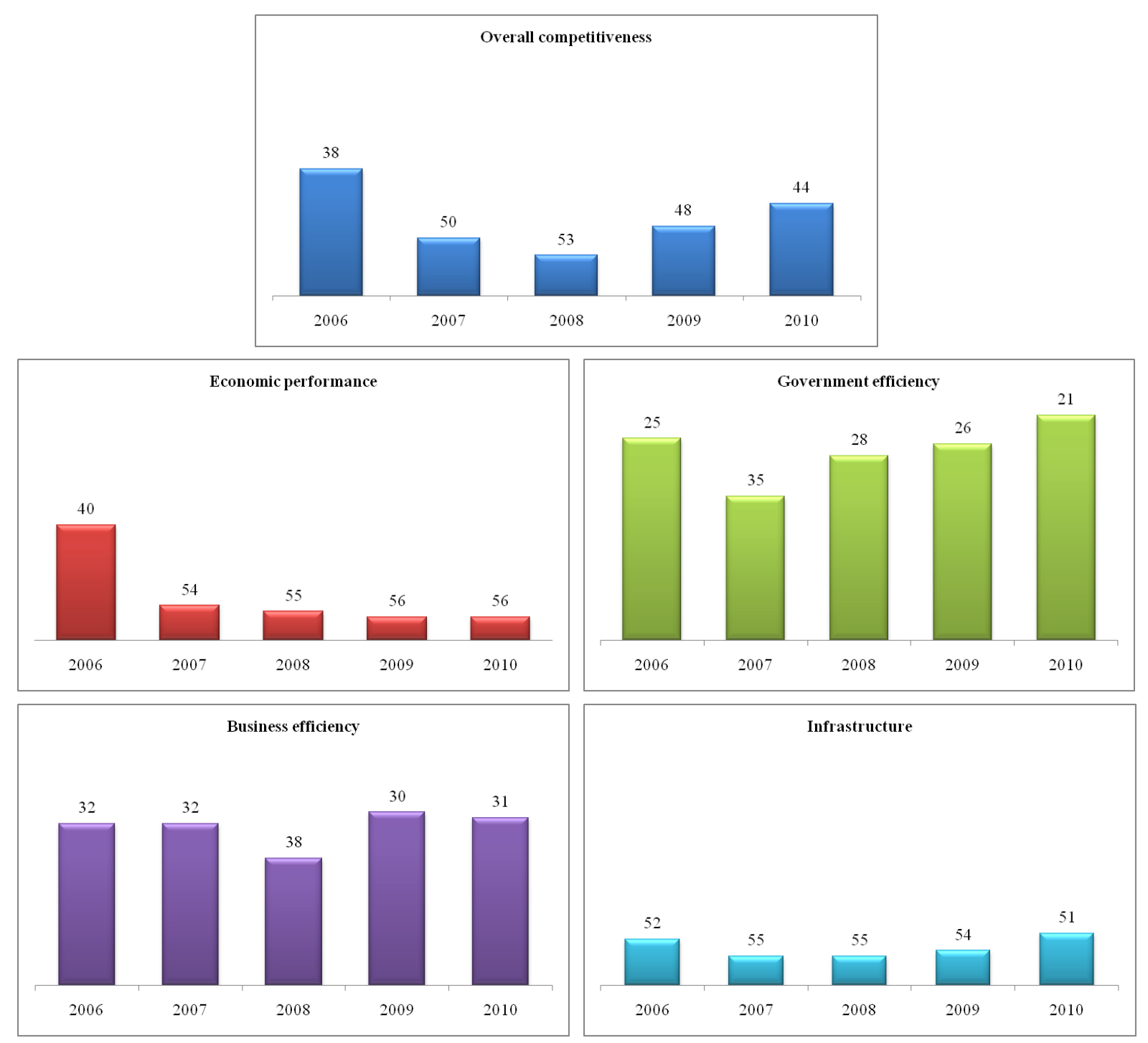

Key: Rank order between 1 (most competitive) and 58 (worst competitive) nation

Figure 1: South Africa's competitiveness performance by IMD ranking - 2006 to 2010 
Table 1: Developing countries by region/IMD competitiveness ranking and score (2010)

\begin{tabular}{|c|c|c|}
\hline $\begin{array}{c}\text { Region/IMD competitiveness } \\
\text { ranking } \\
\text { (out of } 58)\end{array}$ & $\begin{array}{l}\text { IMD score } \\
\text { (out of 100) }\end{array}$ & Country/Nation* \\
\hline \multicolumn{3}{|l|}{ Africa } \\
\hline 44 & 54,092 & South Africa \\
\hline \multicolumn{3}{|l|}{ Asia } \\
\hline $\begin{array}{l}10 \\
18 \\
23 \\
26 \\
31 \\
35 \\
39\end{array}$ & $\begin{array}{l}87,228 \\
80,182 \\
76,249 \\
73,233 \\
64,567 \\
60,745 \\
56,526 \\
\end{array}$ & $\begin{array}{l}\text { Malaysia } \\
\text { China (mainland) } \\
\text { Korea } \\
\text { Thailand } \\
\text { India } \\
\text { Indonesia } \\
\text { Philippines }\end{array}$ \\
\hline \multicolumn{3}{|l|}{ Europe including East European } \\
\hline $\begin{array}{l}29 \\
32 \\
33 \\
34 \\
42 \\
43 \\
48 \\
49 \\
51 \\
53 \\
54 \\
56 \\
57\end{array}$ & $\begin{array}{l}65,443 \\
64,482 \\
63,418 \\
62,641 \\
54,124 \\
54,098 \\
51,119 \\
51,092 \\
49,318 \\
47,756 \\
47,481 \\
40,056 \\
39,948\end{array}$ & $\begin{array}{l}\text { Czech Republic\# } \\
\text { Poland\# } \\
\text { Kazakhstan\# } \\
\text { Estonia\# } \\
\text { Hungary\# } \\
\text { Lithuania\# } \\
\text { Turkey } \\
\text { Slovak Republic\# } \\
\text { Russia\# (though considered one of the G8 countries) } \\
\text { Bulgaria\# } \\
\text { Romania\# } \\
\text { Croatia } \\
\text { Ukraine }\end{array}$ \\
\hline \multicolumn{3}{|l|}{ Middle East } \\
\hline 50 & 49,642 & Jordan \\
\hline $\begin{array}{l}\text { North \& Central America } \\
47\end{array}$ & 51,481 & Mexico \\
\hline \multicolumn{3}{|l|}{ South America } \\
\hline $\begin{array}{l}28 \\
38 \\
41 \\
45 \\
55 \\
58\end{array}$ & $\begin{array}{l}69,669 \\
56,531 \\
54,178 \\
53,890 \\
46,935 \\
27,970 \\
\end{array}$ & $\begin{array}{l}\text { Chile } \\
\text { Brazil } \\
\text { Peru } \\
\text { Colombia } \\
\text { Argentina } \\
\text { Venezuela }\end{array}$ \\
\hline
\end{tabular}

*Classification of developing countries based on the list by Australian Government for receiving overseas aid (AusAid) as updated July 2009 and the list of developing countries published by the American Mathematical Society (AMS)\# for 2010. 


\begin{tabular}{|c|c|c|c|c|c|}
\hline & $\begin{array}{c}\text { Very good } \\
(1-10)\end{array}$ & $\begin{array}{c}\text { Good } \\
(11-20)\end{array}$ & $\begin{array}{l}\text { Average } \\
(21-30)\end{array}$ & $\begin{array}{c}\text { Poor } \\
(31-40)\end{array}$ & $\begin{array}{c}\text { Very poor } \\
(41-58)\end{array}$ \\
\hline $\begin{array}{l}\text { Domestic } \\
\text { economy }\end{array}$ & I & & & & \\
\hline $\begin{array}{l}\text { International } \\
\text { trade }\end{array}$ & $I$ & & & & \\
\hline $\begin{array}{l}\text { International } \\
\text { investment }\end{array}$ & I & & & & \\
\hline Employment & 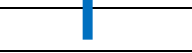 & & & & \\
\hline \multicolumn{6}{|l|}{ Prices } \\
\hline \multicolumn{6}{|l|}{ Public finance } \\
\hline \multicolumn{6}{|l|}{ Fiscal policy } \\
\hline $\begin{array}{l}\text { Intellectual } \\
\text { framework }\end{array}$ & I & & & & \\
\hline $\begin{array}{l}\text { Business } \\
\text { legislation }\end{array}$ & I & & & & \\
\hline \multicolumn{6}{|l|}{$\begin{array}{l}\text { Societal } \\
\text { framework }\end{array}$} \\
\hline \multicolumn{6}{|l|}{$\begin{array}{l}\text { Productivity } \\
\text { and efficiency }\end{array}$} \\
\hline \multicolumn{6}{|l|}{ Labour market } \\
\hline Finance & 7 & 2 & & & \\
\hline $\begin{array}{l}\text { Management } \\
\text { practices }\end{array}$ & 1 & & & & \\
\hline \multicolumn{6}{|l|}{$\begin{array}{l}\text { Attitudes and } \\
\text { values }\end{array}$} \\
\hline \multicolumn{6}{|l|}{$\begin{array}{l}\text { Basic } \\
\text { infrastructure }\end{array}$} \\
\hline $\begin{array}{l}\text { Tech. } \\
\text { infrastructure }\end{array}$ & 1 & & & & \\
\hline $\begin{array}{l}\text { Scientific } \\
\text { infrastructure }\end{array}$ & 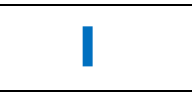 & & & & \\
\hline \multicolumn{6}{|l|}{$\begin{array}{l}\text { Health and } \\
\text { environment }\end{array}$} \\
\hline Education & & & & & \\
\hline
\end{tabular}

Figure 2: South Africa's 2010 relative competitive performance in terms of the 20 IMD individual competitive factors

\subsection{South Africa's economic transformation since 1994}

Numerous dramatic changes have occurred in South Africa on many different fronts since the first, non-racial, all democratic elections held on 27 April 1994. The majority party (the ANC) in this and the next three elections - in 1999, 2004 and 2009 - formed successive governments that have enacted legislation measures aimed at South Africa's economic transformation and implementing a strategy for broad-based black economic empowerment (B-BBEE) (DTI, 2007a).

For the purposes of this study, a collective concept or construct, namely "transformational policies", was derived from a possible combination (theoretical proposition) of five emerging or dominant and contemporary political, social and economic philosophies. These included black economic empowerment (BEE), affirmative action (AA), Ubuntu, Afro-centralism and socio-protectionism. Note: the purpose of the research was not to investigate or analyse the construct "transformational policies" per se, but instead to observe the perceived influence of the collective construct on the competitiveness of businesses operating in South Africa.

Of these five individual concepts, AA is probably the best known, given its introduction in the USA in the early 1960s by President John F. Kennedy under executive order 10925. While the intended beneficiaries in the USA were the socalled "racial or ethnic minorities" of the population, AA practice in South Africa applies to the $90 \%+$ majority of the population (Black \& Geletkanycz, 2006). Whilst AA is not legislated in South Africa per se, Kovacevic (2007) notes that probably the world's most rigorous form of it, namely BEE, has been legislated under the concept of broad-based 
black economic empowerment (B-BBEE). This wider encompassing form of AA has become the predominant and driving ideology of the ANC government (Hamann, Khagram \& Rohan, 2008; Mohammed \& Roberts, 2008). It is defined by the South African Department of Trade and Industry (DTI, 2007a) as "a specific government policy to advance economic transformation and enhance the economic participation of black people in the South African economy" (http://www.thedti.gov.za/bee).

Given the amount of information in terms of the rationale, codes of practice, and so forth that is available on the DTI's website (http://www.thedti.gov.za), it is quite apparent that BEE (under the legislative framework of the B-BEE Act 53 of 2003) and the 2007 B-BBEE Codes of Good Practice (DTI, 2007b) have experienced a rapid metamorphosis and become part and parcel of South Africa's everyday business life (Chabane, Goldstein \& Roberts, 2006). It should be noted, however, that BEE is not without its critics. An example is Moeletsi Mbeki (brother of the former president of South Africa, Thabo Mbeki who, during his premiership from 1999 to 2008, was probably most instrumental in enacting legislation to "formalise" BEE) (Mbeki, 2009:61) who vehemently argues " ... it [BEE] strikes the fatal blow against the emergence of black entrepreneurship by creating a small class of unproductive but wealthy black crony capitalists made up of ANC politicians, some retired and others not, who have become strong allies of the economic oligarchy". He also cynically observes that "BEE and its subsidiaries - affirmative action and affirmative procurement - have metamorphosed ... they have become both the core black ideology of the black political elite and, simultaneously, the driving material and enrichment agenda which is to be achieved by maximising the process of reparations that accrue to the political elite" (Mbeki, 2009:61).

Other authors, such as Hamann et al. (2008:25), have noted with concern the apparent lack of progress BEE has made in rectifying the legacies of apartheid because “... ten years later many of the challenges remain or have become even more acute in terms of poverty, unemployment, housing and basic services, inequality, HIV/AIDS". In addition, Kovacevic (2007:6) observes that “... the program has achieved little success in eradicating poverty, increasing employment or fostering economic growth".

The concept of Ubuntu is now acknowledged as also being part of South African leadership and managerial literature and practice (Smit, Cronjé, Brevis \& Vrba, 2010). According to Black and Geletkanycz (2006:106), the concept of Ubuntu reflects the African spirit of "humaneness that individuals display for one another" encompassing caring, community, harmony, hospitality, respect and responsiveness. It further manifests "in relationships with others that are reciprocal, an oral tradition of language and communication, decision-making by consensus, a broader concept of time as a healer rather that a finite commodity, the optimization of productivity through solidarity, social harmony, shared rewards, a respect for age and leadership, and a belief in a creator, Unkulunkulu, the powers of spiritual healing and an afterlife, the mesocosmos".
The four salient principles of Ubuntu as summarised by Mfuniselwa Bhengu (1996), according to Black and Geletkanycz (2006:106), include the principles of morality, interdependence, the spirit of man and totality (i.e. the collective participation by all in the organisation) and may "simultaneously affect the management issues of coordination, communication, competence, competitiveness, and compassion". Ubuntu thus upholds the value of a greater community (us), rather than the Western values of individualism (me), involvement and benefit. It recognises certain characteristics of African employees, such as the "propensity for collaboration, a desire for demonstration of mutual respect, the necessity for oral communication, and an acknowledgement of the extended family".

Finally, the last two of the five interwoven concepts defining the construct "transformational policies" were, by themselves, derived from informal observation and understanding of African-founded and prevalent philosophies, ideologies and socio-political and economic approaches. Afro-centralism is meant to describe an approach that is predominant in many African countries where political and economic control is centralised in the hands of the ruling party and government. The socioprotectionism concept refers to the African practice of being more socially responsive in pursuance of the inclusivity of communities.

\section{Research design and methodology}

\subsection{Conceptual research framework}

The previous conceptual research framework used in Krüger's study (1997) was adopted as the basis for the 2009 study, although it was amended to allow for the enlarged scope. Figure 3 illustrates the amended conceptual research framework. This framework has five main focus points, of which point 5 is particularly relevant to this article (focus points 1, 2, 3 and 4 are discussed in a separate article). Focus point 5 deals with the impact of "transitional policies" on the competitive operations priorities of South African companies in terms of their general feeling towards such practices and the probable influence that such transformational policies could have on the South African companies' ability to: attain targets; improve on their competitive operations priorities; and compete nationally and internationally.

\subsection{Research population}

The research population consisted of individuals who were either the Chief Executive Officer or Managing Director the Director: Operations or who held a similar, senior managerial position in the company - see table 2. The personal contact details (name, address and email) of the targeted individuals were obtained from the top 100 listed JSE companies (based on turnover) and a further selection of the top 500 of South Africa's best companies (2008 edition). The size of the companies ranged from those employing fewer than 250 people to those with more than 750 employees - see Table 3 . These companies operated in a wide variety of industries (see Table 4). 


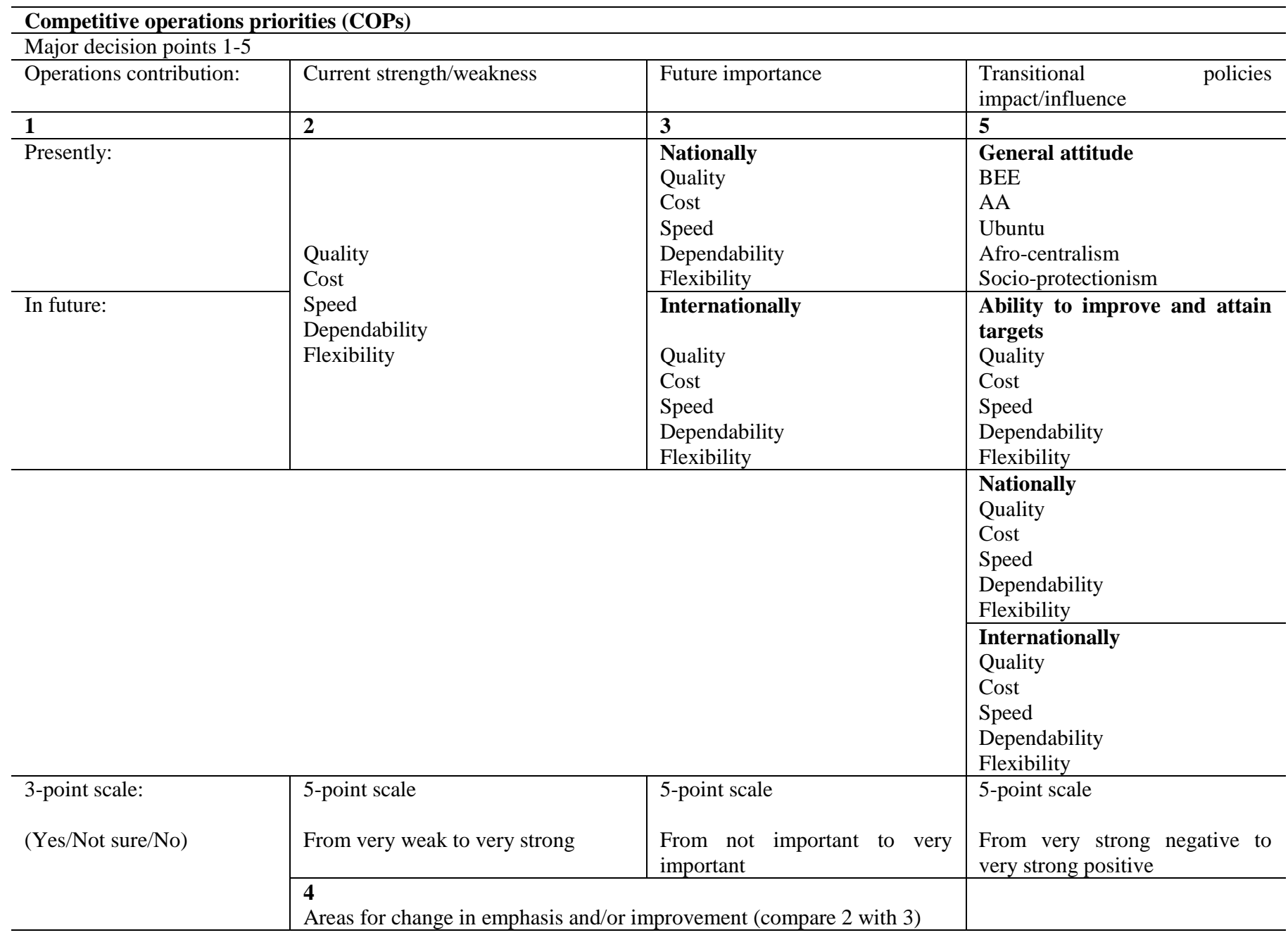

Figure 3: Conceptual research framework: 2009

\subsection{Data collection procedures}

While the 1996 study made use of printed questionnaires that were posted to the physical addresses of the CEOs of some 500 companies listed as manufacturers, the 2009 study was more progressive, and reflected recent IT advances. Online surveys have become popular owing to their many advantages, such as speed of delivery, quick response, convenience of respondent, simplicity in data capturing, more reliable data analysis, etc. (note, however, that there may inherent problem areas to consider as well). As with any survey (postal or on-line), measures must be put in place to ensure that the data obtained are reliable and valid. To improve reliability, the on-line survey was first sent electronically to ten of the envisaged 100 participants and these participants were asked (in addition to completing the questionnaire itself) to give their comments about the suitability, clarity, etc. of the survey instrument. Note: in all cases where electronic surveys were sent to respondents, the individual e-mail addresses were obtained and verified before the questionnaire was dispatched.

A total of 144 e-mails were sent out to the targeted research population. In the end, 104 completed responses were solicited (36 were on-line and a further 68 were telephonic interviews), which represents an excellent response rate of $72 \%$. The telephonic interview route was later taken as a result of the low on-line response rate and because of the relative small sample size. The low on-line response rate is possibly due to time limitations (the respondents work in private companies where time is normally at a premium) and/or respondent fatigue (many complained that they were inundated with a number of on-line surveys at any point in time); alternatively, it may suggest a genuine lack of interest in the research topic.

\section{Research results}

\subsection{Company position occupied}

The position occupied by the respondents in the company is shown in Table 2 . The majority of respondents (43\%) were senior operations managers and the second largest group (30\%) consisted of respondents who were the actual managing directors or CEOs of the company. Combined, a total of 73 per cent of the respondents came from the top or upper-level positions in the company's management hierarchy. This may in fact be interpreted as a positive outcome, given the nature of the topic which is more strategic and thus the confidence in their ability to answer such questions with insight. 


\subsection{Company size}

In terms of company size, the majority (46\%) employed more than 750 people, the second largest group (20\%), however, consisted of companies that employed fewer than 250 people (see Table 3 ). Combined, probably more than 90 per cent of the companies would thus fall within the ambit of the BEE charter and would know about the requirements of this charter. They should also be fully aware of the impact that conforming to BEE regulations has on their companies' operations.

Table 2: Company position occupied

\subsection{Company industry involvement}

The industry involvement of the South African businesses employing the respondents covers some 20 different industries (Table 4). Respondents came from both traditional manufacturing companies and service providers. In short, the sample can be regarded as being representative of a wide range of industries.

\begin{tabular}{l|c|c}
\hline CEO or MD & 31 & 29,8 \\
\hline Director of operations or production manager & 43 & 41,3 \\
\hline Other & 30 & 28,8 \\
\hline Total & 104 & 100 \\
\hline
\end{tabular}

Table 3: Company size

\begin{tabular}{l|c|c}
\hline & Frequency & Per cent \\
\hline Fewer than 250 & 21 & 20,2 \\
\hline More than 250 but fewer than 500 & 16 & 15,4 \\
\hline More than 500 but fewer than 750 & 19 & 18,3 \\
\hline More than 750 & 48 & 46,2 \\
\hline Total & 104 & 100 \\
\hline
\end{tabular}

Table 4: Company industry involvement

\begin{tabular}{|c|c|c|}
\hline & Frequency & Per cent \\
\hline Food, beverage and tobacco & 9 & 8,7 \\
\hline Textiles, clothing and footwear & 12 & 11,5 \\
\hline Pharmaceuticals & 5 & 4,8 \\
\hline Chemicals and petroleum & 6 & 5,8 \\
\hline Hotel, catering and restaurants & 1 & 1 \\
\hline Medical service, hospitals and clinics & 1 & 1 \\
\hline Entertainment incl. sport, theatre & 4 & 3,8 \\
\hline Basic metals products & 6 & 5,8 \\
\hline Fabricated metals products & 4 & 3,8 \\
\hline Transport equipment & 2 & 1,9 \\
\hline Electronics and electrical equipment & 10 & 9,6 \\
\hline Other machinery and equipment & 4 & 3,8 \\
\hline Professional services & 4 & 3,8 \\
\hline Trading, warehousing, wholesale & 11 & 10,6 \\
\hline Property & 1 & 1 \\
\hline Financial & 11 & 10,6 \\
\hline Mining & 1 & 1 \\
\hline Other & 12 & 11,5 \\
\hline Total & 104 & 100 \\
\hline
\end{tabular}




\subsection{Respondents' views on 'transformational policies"}

The first question, in part $\mathrm{D}$ of the research questionnaire, tried to determine the respondents' views on certain "transformational policies" and "African managerial philosophies". The results are shown in Table 5 and the test for significance in Table 6. The majority (57\%) of the respondents felt strongly positive and a further (24\%) very strongly positive about BEE. Combined, therefore, this means that some 81 per cent of the respondents were supportive of BEE. In the case of AA, which is a broader concept than BEE - because it also includes other minority groups irrespective of their race categorisation alone - such as the disabled, the majority (45\%) were strongly and a further 15 per cent very strongly positive. A large proportion $(31 \%)$ indicated they had no firm opinion either positively or negatively. In the case of the African managerial philosophy of Ubuntu, the majority (54\%) indicated they had no opinion, while a combined 40 per cent of respondents were strongly or very strongly positive towards the approach.

Afro-centralism, a term derived from the practice of centralising all or most political and economic power in government, drew a "no opinion" response from the majority (70\%). Otherwise, both strong negative (12\%) and strong positive $(17 \%)$ feelings were expressed. It thus appears that respondents were largely unfamiliar with the term. Finally, as far as socio-protectionism (which is derived from the African practice of being more socially responsive and pursuing the inclusivity of communities) was concerned, a large majority (64\%) also had no opinion on the concept). Combined, 28 per cent of the respondents indicated they felt strongly or very strongly negative, with only about 8 per cent being positively inclined. Again, it seems that respondents were largely unfamiliar with the term.

Table 5: General feelings toward transitional policies and African philosophies

\begin{tabular}{|c|c|c|c|c|c|c|c|c|c|c|}
\hline & \multicolumn{2}{|c|}{ BEE } & \multicolumn{2}{|c|}{$\mathbf{A A}$} & \multicolumn{2}{|c|}{ Ubuntu } & \multicolumn{2}{|c|}{ Afro-centralism } & \multicolumn{2}{|c|}{ Socio-protectionism } \\
\hline & Frequency & $\begin{array}{l}\text { Per } \\
\text { cent }\end{array}$ & Frequency & $\begin{array}{l}\text { Per } \\
\text { cent }\end{array}$ & Frequency & $\begin{array}{l}\text { Per } \\
\text { cent }\end{array}$ & Frequency & $\begin{array}{l}\text { Per } \\
\text { cent }\end{array}$ & Frequency & $\begin{array}{l}\text { Per } \\
\text { cent }\end{array}$ \\
\hline $\begin{array}{l}\text { Very strong } \\
\text { negative }\end{array}$ & 6 & 5,769 & 3 & 2,885 & 1 & 0,962 & & & 5 & 4,800 \\
\hline $\begin{array}{l}\text { Strong } \\
\text { negative }\end{array}$ & & & 6 & 5,769 & 4 & 3,846 & 12 & 11,500 & 24 & 23,100 \\
\hline No opinion & 14 & 13,462 & 32 & 30,769 & 57 & 54,808 & 73 & 70,200 & 66 & 63,500 \\
\hline $\begin{array}{l}\text { Strong } \\
\text { positive }\end{array}$ & 59 & 56,731 & 47 & 45,192 & 30 & 28,846 & 18 & 17,300 & 8 & 7,700 \\
\hline $\begin{array}{l}\text { Very strong } \\
\text { positive }\end{array}$ & 25 & 24,038 & 16 & 15,385 & 12 & 11,538 & 1 & 1,000 & 1 & 1,000 \\
\hline Total & 104 & 100 & 104 & 100 & 104 & 100 & 104 & 100 & 104 & 100 \\
\hline Mean & \multicolumn{2}{|c|}{3,933} & \multicolumn{2}{|c|}{3,644} & \multicolumn{2}{|c|}{3,462} & \multicolumn{2}{|c|}{3,077} & \multicolumn{2}{|c|}{2,769} \\
\hline $\begin{array}{l}\begin{array}{l}\text { Std. } \\
\text { deviation }\end{array} \\
\end{array}$ & \multicolumn{2}{|c|}{0,948} & \multicolumn{2}{|c|}{0,913} & \multicolumn{2}{|c|}{0,787} & \multicolumn{2}{|c|}{0,569} & \multicolumn{2}{|c|}{0,700} \\
\hline Variance & \multicolumn{2}{|c|}{0,898} & \multicolumn{2}{|c|}{0,833} & \multicolumn{2}{|c|}{0,620} & \multicolumn{2}{|c|}{0,324} & \multicolumn{2}{|c|}{0,490} \\
\hline Minimum & \multicolumn{2}{|l|}{1} & \multicolumn{2}{|l|}{1} & \multicolumn{2}{|l|}{1} & \multicolumn{2}{|l|}{2} & \multicolumn{2}{|l|}{1} \\
\hline Maximum & \multicolumn{2}{|l|}{5} & \multicolumn{2}{|l|}{5} & \multicolumn{2}{|l|}{5} & \multicolumn{2}{|l|}{5} & \multicolumn{2}{|l|}{5} \\
\hline
\end{tabular}

Table 6: Significance test with test value $=$ no opinion

\begin{tabular}{l|c|c|c|c|c|c}
\hline & t & df & Sig. (2-tailed) & Mean difference & \multicolumn{2}{|c}{ 95\% Confidence interval of the } \\
difference
\end{tabular}


When compared with the median test value = no opinion, the strong positive feeling towards BEE showed the greatest significance, followed by significantly positive feelings towards AA and Ubuntu. However, the little significance that is similarly indicated for the general attitude towards Afro-centralism shows that this concept is not known to respondents and they therefore have no opinion about it. Regarding the respondents' general feeling towards socioprotectionism, a significantly strong negative perception is indicated when compared with the medium test value $=$ no opinion.

\subsection{Influence of transformational policies on companies' ability to attain targets in each of the competitive operations priorities (COPs)}

The second question in part $\mathrm{D}$ focused on what respondents perceived the probable impact or influence of BEE would be on the company's ability to attain its targets in each of the five COPs. The results are shown in Table 7 and the test for significance in Table 8 . In most cases, the majority of respondents (above between 55 and 65\%) offered "no opinion" of what might be the impact of such transformational policies on their competitive operations priorities. Only in the case of "low cost" did the majority (43\%) express some negative sentiments about the probable impact of BEE and AA.
When compared with the median test value = no opinion, the impact of BEE and AA on the company's ability to attain its quality targets showed some significant positive support. However, similarly compared, the respondents had no opinion about what the impact of BEE and AA would be on the company's ability to attain its targets in terms of cost, speediness, dependability and flexibility.

\subsection{Influence of transformational policies on a company's ability to improve its performance in each of the COPs}

The third question in part D similarly focused on what respondents felt the probable impact or influence of BEE would have on the company's ability to improve its performance in each of the five COPs. Again, the results are indicated in Table 9 and the test for significance in table 10. In all cases, the majority (above between 40 and $73 \%$ ) of the respondents indicated they had "no opinion" of what the impact could be. In the case of quality and speediness, the second largest group of respondents indicated some positive sentiments, while in the case of cost, dependability and flexibility, they were, however, more negatively inclined.

Table 7: Impact/influence of BEE and AA on company to attain targets in terms of its competitive operations priorities

\begin{tabular}{|c|c|c|c|c|c|c|c|c|c|c|}
\hline & \multirow{2}{*}{\multicolumn{2}{|c|}{$\begin{array}{l}\text { Quality } \\
\text { Ability to } \\
\text { improve }\end{array}$}} & \multirow{2}{*}{\multicolumn{2}{|c|}{$\begin{array}{c}\text { Cost } \\
\begin{array}{c}\text { Ability to } \\
\text { improve }\end{array} \\
\end{array}$}} & \multirow{2}{*}{\multicolumn{2}{|c|}{$\begin{array}{l}\text { Speediness } \\
\text { Ability to } \\
\text { improve } \\
\end{array}$}} & \multirow{2}{*}{\multicolumn{2}{|c|}{$\begin{array}{c}\text { Dependability } \\
\text { Ability to improve }\end{array}$}} & \multirow{2}{*}{\multicolumn{2}{|c|}{$\begin{array}{l}\text { Flexibility } \\
\text { Ability to } \\
\text { improve }\end{array}$}} \\
\hline & & & & & & & & & & \\
\hline & Freq & $\%$ & Freq & $\%$ & Freq & $\%$ & Freq & $\%$ & Freq & $\%$ \\
\hline \multicolumn{11}{|l|}{ Very strong negative } \\
\hline Strong negative & 13 & 12,5 & 45 & 43,3 & 14 & 13,5 & 19 & 18,3 & 14 & 13,5 \\
\hline No opinion & 58 & 55,8 & 34 & 32,7 & 68 & 65,4 & 59 & 56,7 & 66 & 63,5 \\
\hline Strong positive & 28 & 26,9 & 21 & 20,2 & 17 & 16,3 & 21 & 20,2 & 19 & 18,3 \\
\hline Very strong positive & 5 & 4,8 & 4 & 3,8 & 5 & 4,8 & 5 & 4,8 & 5 & 4,8 \\
\hline Total & 104 & 100,0 & 104 & 100,0 & 104 & 100,0 & 104 & 100,0 & 104 & 100,0 \\
\hline Mean & \multicolumn{2}{|c|}{3,240} & \multicolumn{2}{|c|}{2,846} & \multicolumn{2}{|c|}{3,125} & \multicolumn{2}{|c|}{3,115} & \multicolumn{2}{|c|}{3,144} \\
\hline Std. deviation & \multicolumn{2}{|c|}{0,731} & \multicolumn{2}{|c|}{0,879} & \multicolumn{2}{|c|}{0,692} & \multicolumn{2}{|c|}{0,754} & \multicolumn{2}{|c|}{0,703} \\
\hline Variance & \multicolumn{2}{|c|}{0,534} & \multicolumn{2}{|c|}{0,772} & \multicolumn{2}{|c|}{0,479} & \multicolumn{2}{|c|}{0,569} & \multicolumn{2}{|c|}{0,494} \\
\hline Minimum & \multicolumn{2}{|c|}{2} & \multicolumn{2}{|c|}{2} & \multicolumn{2}{|c|}{2} & \multicolumn{2}{|c|}{2} & \multicolumn{2}{|c|}{2} \\
\hline Maximum & \multicolumn{2}{|c|}{5} & \multicolumn{2}{|c|}{5} & \multicolumn{2}{|c|}{5} & \multicolumn{2}{|c|}{5} & \multicolumn{2}{|c|}{5} \\
\hline
\end{tabular}


Table 8: Significance test with test value $=$ no opinion

\begin{tabular}{l|r|c|c|c|c|c}
\hline Ability to attain targets & $\mathbf{t}$ & Df & Sig. (2-tailed) & Mean difference & \multicolumn{2}{|c}{$\begin{array}{c}\text { 95\% confidence interval of the } \\
\text { difference }\end{array}$} \\
\hline & & & & & \multicolumn{2}{c}{ Lower } \\
\hline Quality & 3,355 & 103 &, 001 &, 24038 &, 0983 &, 3825 \\
\hline Cost & $-1,785$ & 103 &, 077 &,- 15385 &,- 3247 &, 0171 \\
\hline Speediness & 1,841 & 103 &, 068 &, 12500 &,- 0096 &, 2596 \\
\hline Dependability & 1,560 & 103 &, 122 &, 11538 &,- 0313 &, 2621 \\
\hline Flexibility & 2,094 & 103 &, 039 &, 14423 &, 0076 &, 2809 \\
\hline
\end{tabular}

Table 9: Impact/influence of BEE and AA on the company to improve on its competitive operations priorities

\begin{tabular}{|c|c|c|c|c|c|c|c|c|c|c|}
\hline & \multicolumn{2}{|c|}{ Quality } & \multicolumn{2}{|c|}{ Cost } & \multicolumn{2}{|c|}{ Speediness } & \multicolumn{2}{|c|}{ Dependability } & \multicolumn{2}{|c|}{ Flexibility } \\
\hline & \multicolumn{2}{|c|}{$\begin{array}{c}\text { Ability to } \\
\text { improve }\end{array}$} & \multicolumn{2}{|c|}{$\begin{array}{l}\text { Ability to } \\
\text { improve }\end{array}$} & \multicolumn{2}{|c|}{$\begin{array}{l}\text { Ability to } \\
\text { improve }\end{array}$} & \multicolumn{2}{|c|}{ Ability to improve } & \multicolumn{2}{|c|}{$\begin{array}{c}\text { Ability to } \\
\text { improve }\end{array}$} \\
\hline & Freq & $\%$ & Freq & $\%$ & Freq & $\%$ & Freq & $\%$ & Freq & $\%$ \\
\hline \multicolumn{11}{|l|}{ Very strong negative } \\
\hline Strong negative & 9 & 8,7 & 37 & 35,9 & 9 & 8,7 & 14 & 13,6 & 20 & 19,6 \\
\hline No opinion & 71 & 68,9 & 42 & 40,8 & 76 & 73,8 & 74 & 71,8 & 60 & 58,8 \\
\hline Strong positive & 18 & 17,5 & 24 & 23,3 & 13 & 12,6 & 10 & 9,7 & 17 & 16,7 \\
\hline Very strong positive & 5 & 4,9 & & & 5 & 4,9 & 5 & 4,9 & 5 & 4,9 \\
\hline Total & 103 & 100,0 & 103 & 100,0 & 103 & 100,0 & 103 & 100,0 & 102 & 100,0 \\
\hline Mean & \multicolumn{2}{|c|}{3,185} & \multicolumn{2}{|c|}{2,874} & \multicolumn{2}{|c|}{3,136} & \multicolumn{2}{|c|}{3,058} & \multicolumn{2}{|c|}{3,069} \\
\hline Std. deviation & \multicolumn{2}{|c|}{0,653} & \multicolumn{2}{|c|}{0,763} & \multicolumn{2}{|c|}{0,627} & \multicolumn{2}{|c|}{0,654} & \multicolumn{2}{|c|}{0,748} \\
\hline Variance & \multicolumn{2}{|c|}{0,426} & \multicolumn{2}{|c|}{0,582} & \multicolumn{2}{|c|}{0,393} & \multicolumn{2}{|c|}{0,428} & \multicolumn{2}{|c|}{0,560} \\
\hline Minimum & \multicolumn{2}{|c|}{2} & \multicolumn{2}{|c|}{2} & \multicolumn{2}{|c|}{2} & \multicolumn{2}{|c|}{2} & \multicolumn{2}{|c|}{2} \\
\hline Maximum & \multicolumn{2}{|c|}{5} & \multicolumn{2}{|c|}{4} & \multicolumn{2}{|c|}{5} & \multicolumn{2}{|c|}{5} & \multicolumn{2}{|c|}{5} \\
\hline
\end{tabular}

Table10: Significance test with test value = no opinion

\begin{tabular}{l|c|c|c|c|c|c}
\hline \multicolumn{1}{c|}{ Ability to improve } & $\mathbf{t}$ & $\mathbf{d f}$ & Sig. (2-tailed) & Mean difference & \multicolumn{2}{c}{ 95\% confidence interval of the } \\
difference
\end{tabular}


When compared with the median test value = no opinion, the impact of BEE and AA on the company's ability to improve on its quality targets showed some significant positive support. However, similarly compared, the respondents had no opinion about what the impact of BEE and AA would be on the company's ability to improve on its targets in terms cost, speediness, dependability and flexibility.

5.7 Influence of transformational policies on companies' ability to compete nationally in each of the COPs

The fourth question specifically focused on the probable impact or influence that "transformational policies" such as BEE and AA could have on the company's ability to compete nationally. The results in terms of the company's ability to compete nationally are shown in Table 11 and the test for significance in Table 12. In all cases, the majority (above between 45 and $75 \%$ ) of the respondents indicated that they had "no opinion". Some negative sentiments were expressed about cost, while similarly, some positive sentiments were expressed about quality, speediness, dependability and flexibility.

When compared with the median test value = no opinion, the impact of BEE and AA on the company's ability to compete nationally to meet its quality targets showed some significant positive support. However, similarly compared, the respondents had no opinion about what the impact of BEE and AA would be on the company's ability to compete nationally to meet its targets in terms of cost, speediness, dependability and flexibility. What is your view on this?

Table 11: Impact/influence of BEE and AA on the company's ability to compete nationally

\begin{tabular}{|c|c|c|c|c|c|c|c|c|c|c|}
\hline & \multicolumn{2}{|c|}{ Quality } & \multicolumn{2}{|c|}{ Cost } & \multicolumn{2}{|c|}{ Speediness } & \multicolumn{2}{|c|}{ Dependability } & \multicolumn{2}{|c|}{ Flexibility } \\
\hline & Frequency & $\begin{array}{l}\text { Per } \\
\text { cent }\end{array}$ & Frequency & $\begin{array}{l}\text { Per } \\
\text { cent }\end{array}$ & Frequency & $\begin{array}{l}\text { Per } \\
\text { cent }\end{array}$ & Frequency & $\begin{array}{l}\text { Per } \\
\text { cent }\end{array}$ & Frequency & $\begin{array}{l}\text { Per } \\
\text { cent }\end{array}$ \\
\hline \multicolumn{11}{|l|}{$\begin{array}{l}\text { Very strong } \\
\text { negative }\end{array}$} \\
\hline $\begin{array}{l}\text { Strong } \\
\text { negative }\end{array}$ & 12 & 11,50 & 34 & 33,00 & 10 & 9,62 & 10 & 9,60 & 11 & 10,70 \\
\hline No opinion & 63 & 60,60 & 47 & 45,60 & 78 & 75,00 & 71 & 68,30 & 70 & 68,00 \\
\hline Strong positive & 23 & 22,10 & 21 & 20,40 & 10 & 9,62 & 17 & 16,30 & 17 & 16,50 \\
\hline $\begin{array}{l}\text { Very strong } \\
\text { positive }\end{array}$ & 6 & 5,80 & 1 & 1,00 & 6 & 5,77 & 6 & 5,80 & 5 & 4,90 \\
\hline Total & 104 & 100,00 & 103 & 100,00 & 104 & 100,00 & 104 & 100,00 & 103 & 100,00 \\
\hline Mean & \multicolumn{2}{|c|}{3,221} & \multicolumn{2}{|c|}{2,893} & \multicolumn{2}{|c|}{3,115} & \multicolumn{2}{|c|}{3,1827} & \multicolumn{2}{|c|}{3,155} \\
\hline Std. deviation & \multicolumn{2}{|c|}{0,723} & \multicolumn{2}{|c|}{0,753} & \multicolumn{2}{|c|}{0,643} & \multicolumn{2}{|c|}{0,6793} & \multicolumn{2}{|c|}{0,668} \\
\hline Variance & \multicolumn{2}{|c|}{0,523} & \multicolumn{2}{|c|}{0,567} & \multicolumn{2}{|c|}{0,414} & \multicolumn{2}{|c|}{0,461} & \multicolumn{2}{|c|}{0,446} \\
\hline Minimum & \multicolumn{2}{|l|}{2} & \multicolumn{2}{|c|}{2} & \multicolumn{2}{|c|}{2} & \multicolumn{2}{|l|}{2} & \multicolumn{2}{|l|}{2} \\
\hline Maximum & \multicolumn{2}{|l|}{5} & \multicolumn{2}{|l|}{5} & \multicolumn{2}{|c|}{5} & \multicolumn{2}{|l|}{5} & \multicolumn{2}{|l|}{5} \\
\hline
\end{tabular}

Table 12: Significance test with test value $=$ no opinion

\begin{tabular}{l|c|c|c|c|c|c}
\hline \multicolumn{1}{c|}{ National } & $\mathbf{t}$ & $\mathbf{d f}$ & Sig. (2-tailed) & Mean difference & \multicolumn{2}{c}{$\begin{array}{c}\text { 95\% confidence interval of the } \\
\text { difference }\end{array}$} \\
\hline & & & & & \multicolumn{2}{c}{ Lower } \\
\hline Quality & 2,935 & 101 &, 004 &, 20588 &, 0668 &, 3450 \\
\hline Cost & $-1,587$ & 101 &, 116 &,- 11765 &,- 2647 &, 0294 \\
\hline Speediness & 1,593 & 101 &, 114 &, 09804 &,- 0240 &, 2201 \\
\hline Dependability & 2,545 & 101 &, 012 &, 16667 &, 0368 &, 2966 \\
\hline Flexibility & 2,361 & 101 &, 020 &, 15686 &, 0250 &, 2887 \\
\hline
\end{tabular}


5.8 Influence of transformational policies on companies' ability to compete internationally in each of the COPs

The fifth question specifically focused on the probable impact or influence that transformational policies such as BEE and AA could have on the company's ability to compete internationally. The results in terms of the company's ability to compete internationally are shown in Table 13 and the test for significance in Table 14. The majority (above between 44 and 70\%) of the respondents again opted for the "no opinion" answer. However, the second largest percentage group expressed negative sentiments for all five COPs (i.e. quality, cost, speediness, dependability and flexibility).

When compared with the median test value $=$ no opinion, the respondents had no opinion about what the impact of BEE and AA would be on the company's ability to compete internationally on any of the targets set in terms of quality, cost, speediness, dependability and flexibility.

Table 13: Impact influence of BEE and AA on the company's ability to compete internationally

\begin{tabular}{|c|c|c|c|c|c|c|c|c|c|c|}
\hline & \multicolumn{2}{|c|}{ Quality } & \multicolumn{2}{|c|}{ Cost } & \multicolumn{2}{|c|}{ Speediness } & \multicolumn{2}{|c|}{ Dependability } & \multicolumn{2}{|c|}{ Flexibility } \\
\hline & Frequency & Per cent & Frequency & Per cent & Frequency & Per cent & Frequency & Per cent & Frequency & Per cent \\
\hline $\begin{array}{l}\text { Very strong } \\
\text { negative }\end{array}$ & & & 8 & 7.7 & & & & & & \\
\hline $\begin{array}{l}\text { Strong } \\
\text { negative }\end{array}$ & 32 & 30,8 & 29 & 27,9 & 17 & 16,5 & 21 & 20,2 & 22 & 21,2 \\
\hline No opinion & 51 & 49 & 46 & 44,2 & 72 & 69,9 & 59 & 56,7 & 60 & 57,7 \\
\hline Strong positive & 21 & 20,2 & 16 & 15,4 & 12 & 11,7 & 19 & 18,3 & 17 & 16,3 \\
\hline $\begin{array}{l}\text { Very strong } \\
\text { positive }\end{array}$ & & & 5 & 4,8 & 2 & 1,9 & 5 & 4,8 & 5 & 4,8 \\
\hline Total & 104 & 100,00 & 104 & 100 & 103 & 100 & 104 & 100 & 104 & 100 \\
\hline Mean & \multicolumn{2}{|c|}{2,894} & \multicolumn{2}{|c|}{2,817} & \multicolumn{2}{|c|}{2,990} & \multicolumn{2}{|c|}{3,077} & \multicolumn{2}{|c|}{3,048} \\
\hline Std. deviation & \multicolumn{2}{|c|}{0,709} & \multicolumn{2}{|c|}{0,953} & \multicolumn{2}{|c|}{0,602} & \multicolumn{2}{|c|}{0,759} & \multicolumn{2}{|c|}{0,755} \\
\hline Variance & \multicolumn{2}{|c|}{0,503} & \multicolumn{2}{|c|}{0,908} & \multicolumn{2}{|c|}{0,363} & \multicolumn{2}{|c|}{0,577} & \multicolumn{2}{|c|}{0,570} \\
\hline Minimum & \multicolumn{2}{|c|}{2} & \multicolumn{2}{|c|}{1} & \multicolumn{2}{|c|}{2} & \multicolumn{2}{|c|}{2} & \multicolumn{2}{|c|}{2} \\
\hline Maximum & \multicolumn{2}{|c|}{4} & \multicolumn{2}{|c|}{5} & \multicolumn{2}{|c|}{5} & \multicolumn{2}{|c|}{5} & \multicolumn{2}{|c|}{5} \\
\hline
\end{tabular}

Table 14: Significance test with test value $=$ no opinion

\begin{tabular}{l|c|c|c|c|c|c}
\hline \multicolumn{1}{c|}{ International } & $\mathbf{t}$ & df & Sig. (2-tailed) & Mean difference & \multicolumn{2}{c}{ 95\% confidence interval of the } \\
difference
\end{tabular}

\section{Conclusions and recommendations}

Remarkably, South Africa is the only country on the whole African continent that is included in the world competitiveness rankings conducted annually by the IMD (IMD, 2010b) under the top 50 to 60 nations. Whilst its overall position is still in the bottom quarter of nations (at $44^{\text {th }}$ ), its performance in two of the four main indicators measuring government and business efficiency are surprisingly much better (with $21^{\text {st }}$ and $31^{\text {st }}$ rankings respectively). However, and disappointingly, South Africa's performance in the other two main indicators, economic performance $\left(56^{\text {th }}\right)$ and infrastructure $\left(51^{\text {th }}\right)$, are among the lowest rank performances.
South African businesses need to improve their operational competitiveness both nationally and internationally if they are to further contribute to the country's overall competitiveness. Following the major political events and transformation initiatives such as BEE and AA that have occurred in the country since 1994, South African businesses also need to comply with this legislation and the ensuing industry charters, quotas and preferential treatment of previously disadvantaged individuals or designated groups. It is therefore imperative that South African businesses determine the possible impact and/or influence this compliance has on their COPs. 
In the 2009 survey among the top 100 JSE listed and 500 best companies in South Africa, the majority of respondents (73\%) who were senior managers of large companies (46\%) employing more than 750 people over a range of some 20 different industries, the following results were evident:

- A significant majority were strongly or very strongly in support of BEE, while slightly fewer felt the same towards AA and the managerial philosophy emanating from Africa, namely Ubuntu. These respondents indicated they had no opinion about the new research postulated concepts of Afro-centralism or socioprotectionism.

- The majority of respondents did not offer an opinion about the potential influence of BEE and AA on their company's ability to attain its targets in terms of four of the COPs (cost, speed, dependability and flexibility). However, some significant positive support was indicated in terms of the influence of BEE and AA on companies' ability to achieve their quality targets.

- Similarly, the majority of respondents did not offer an opinion about the potential influence of BEE and AA on their company's ability to improve on its targets in terms of these same four COPs. Again, some significant positive support was indicated in terms of the influence of BEE and AA on companies' ability to improve on their quality targets.

- Disappointingly, the majority of respondents did not offer an opinion about the potential influence of BEE and AA on their company's ability to compete BOTH nationally and internationally in terms of their COPs. Only in the case of competing nationally was some significant positive support expressed in terms of the influence of BEE and AA.

Given the results obtained from the survey, it is clear that, despite the fact that a significant majority of respondents (who are the senior managers in these companies) are seemingly positive about "transformational policies" such as BEE and AA, they do not seem prepared or able to offer an opinion about the potential influence of these policies on their company's ability to attain targets, improve on its performance or compete both national and internationally in terms of its COPs. The potential impact of respondents not actively or deliberately participating in research focusing on BEE and similar topics confirms the dilemma that Fauconnier and Mathur-Helm (2008:1) also set out to address in their study, namely "... to contribute to the literature by attempting to address the gap in BEE dealings, the challenges and the factors for the achievement of success - which are currently unavailable in the literature".

However, accepting that research studies of this nature are bound to be considered sensitive to many, given the past history and legacy of apartheid for which these measures are ostensibly being implemented, the critical comments and damaging observations about BEE practices by prominent individuals and organisations in South Africa today, do indeed demonstrate the absolute moral imperative for much more in-depth and critical attention to this somewhat emotive but national issue by business management academics and practitioners alike.

\section{References}

Bhengu, M.J. 1996. Ubuntu: The essence of democracy. Cape Town: Novalis Press.

Black, S.S. \& Geletkanycz, M.A. 2006. 'The new breed of black South African senior managers: Helping South African businesses meet the challenge of a transforming economy', Organization Management Journal, 2(3): 94114.

Booysen, L. 2007. 'Barriers to employment equity implementation and retention of blacks in management in South Africa', South African Journal of Labour Relations, 31(1): 47-71.

Chabane, N., Goldstein, A. \& Roberts, S. 2006. 'The changing face and strategies of big business in South Africa: More than a decade of political democracy', Industrial and Corporate Change, 15(3):549-577.

De Boer, I. 2009. 'Competitive operations priorities for SA Businesses'. CD received 11 August 2009. Updated report 9 September 2009 and figures 10 August 2010.

Department of Trade and Industry (DTI). 2007a. 'South Africa's economic transformation: A strategy for broadbased economic empowerment'. [online] URL:http://www.thedti.gov.za/bee/bee.htm. Accessed 24 February 2010.

Department of Trade and Industry (DTI). 2007b. Broadbased Black Economic Empowerment Act (53/2003): Codes of Good Practice on Black Economic Empowerment. Government Notice 112. Pretoria: DTI.

Du Toit, A., Kruger, S. \& Ponte, S. 2008. 'Deracializing exploitation? Black economic empowerment in the South African wine industry', Journal of Agrarian Change, 8(1):632.

Evans, J.R. \& Collier, D.A.R. 2007. Operations management: An integrated goods and services approach. Mason, OH: Thomson.

Fauconnier, A. \& Mathur-Helm, B. 2008. 'Black economic empowerment in the South African mining industry: A case study of Exxaro Limited,' South African Journal of Business Management, 39(4): 1-14.

Hayes, R.H. \& Wheelwright, S.C. 1984. Restoring our competitive edge: Competing through manufacturing. New York: Wiley.

Hamann, R., Khagram, S. \& Rohan, S. 2008. 'South Africa's charter approach to post-apartheid economic transformation: Collaborative governance or hardball bargaining?' Journal of South African Studies, 34(1) 21-37. 
Hill, T. 1985. Manufacturing strategy: The strategic management of the manufacturing function. Basingstoke: MacMillan.

Hipkin, I. 2004. 'Determining technology strategy in developing countries', The International Journal of Management Sciences, Omega 32:245-260.

Ihedurua, O.C. 2004. 'Black economic power and nationbuilding in post-apartheid South Africa', The Journal of Modern African Studies, 42(1):1-30.

IMD. 2010a. 'IMD World Competitiveness Yearbook', Lausanne, Switzerland. [online] URL:http://www.imd.ch/research/publications/wcy/upload/s coreboard.pdf. Accessed 16 August 2010.

IMD. 2010b. 'World competitiveness online for South Africa - overall performance'. [online]URL: http://www.worldcompetitiveness.com/. Accessed 25 May 2010.

Kovacevic, N. 2007. 'Righting wrongs: Affirmative action in South Africa', Harvard International Review, Spring: 6.

Kruger, L. 2010. 'Critique by stealth: Aspiration, consumption and class in post-apartheid television drama. Critical Arts: A South-North Journal of Cultural and Media Studies, 24(1): 75-98.

Krüger, L.P. 2010. 'Developing operations strategies: Reassessing the strength and importance of competitive operations priorities for South African businesses'. Submitted to South African Journal of Business Management as unpublished article 10/32 submitted May 2010 .

Krüger, L.P. 1997. 'Strategic manufacturing priorities for South African manufacturers: The need to shift emphasis and improve on current performance levels', South Africa Journal of Business Management, 28(4): 138-146.

Krüger, L.P. 1996. Strategic manufacturing priorities for South African manufacturers. Pretoria: Centre for Business Management, University of South Africa. Published research report.

Mbeki, M. 2009. Architects of poverty: Why African capitalism needs changing. Johannesburg: Picador.

Mohamed, G. \& Roberts, S. 2008. 'Weak links in the BEE chain? Procurement, skills and employment equity in the metals and engineering industries', Journal of Contemporary African Studies, 26(1): 27-50.

Ponte, S., Roberts, S. \& Van Sittert, L. 2007. 'Black economic empowerment, business and the state in South Africa', Development and Change, 38(5): 933-955.

Slack, N., Chambers, S. \& Johnston, R. 2010. Operations management. $6^{\text {th }}$ Edition. Harlow: Pearson.
Smit, P.J., Cronjé, G.J. de J., Brevis, T. \& Vrba, M.J. 2010. Management principles: A contemporary edition for Africa. $4^{\text {th }}$ Edition. Cape Town: Juta.

Vermeulen, L.P. \& Coetzee, M. 2006. 'Perceptions of the dimensions of fairness of affirmative action: A pilot study', South African Journal of Business Management, 37(2): 5365. 